\title{
Current Status of HbA1c Biosensors
}

\author{
Hua Lin and Jun Yi * \\ School of Environmental and Biological Engineering, Nanjing University of Science and Technology, \\ Nanjing 210094, China; linhua@njust.edu.cn \\ * Correspondence: yijun@njust.edu.cn; Tel.: +86-25-8430-3273
}

Received: 24 June 2017; Accepted: 1 August 2017; Published: 4 August 2017

\begin{abstract}
Glycated hemoglobin (HbA1c) is formed via non-enzymatic glycosylation reactions at the $\alpha$-amino group of $\beta$ Val1 residues in the tetrameric $\mathrm{Hb}$, and it can reflect the ambient glycemic level over the past two to three months. A variety of $\mathrm{HbA1c}$ detection methods, including chromatography, immunoassay, enzymatic measurement, electrochemical sensor and capillary electrophoresis have been developed and used in research laboratories and in clinics as well. In this review, we summarize the current status of $\mathrm{HbA} 1 \mathrm{c}$ biosensors based on the recognition of the sugar moiety on the protein and also their applications in the whole blood sample measurements.
\end{abstract}

Keywords: glycated hemoglobin (HbA1c); biosensor; boronic acid; antibody; fructosyl valine

\section{Introduction}

With the worldwide improvement in the living conditions of humans in general, accompanied by problematic changes in diet and life-style habits such as reduced exercise, diabetes mellitus (DM) has become a major epidemic disease. According to the latest report by the International Federation of Clinical Chemistry and Laboratory Medicine (IFCC), there were 415 million people with diabetes around the world, of which $47 \%$ of the patients were unaware of their state of illness [1].

Glycated hemoglobin $(\mathrm{HbA} 1 \mathrm{c})$ is a typical glycosylated protein in the body, and its abundance reflects the average blood glucose level over two to three months, corresponding to the 100- to 120-day lifespan of erythrocytes. The $\mathrm{HbA1c}$ level can not only be used by diabetes patients to monitor their long-term glucose management in a way that is not affected by fluctuations of the blood-glucose level, but also can be used by doctors to assess potential risks of diabetes complications of patients. In 2010 and 2011 the American Diabetes Association (ADA) and World Health Organization (WHO) have recommended a diagnostic cut-off point of $\geq 6.5 \% \mathrm{HbA} 1 \mathrm{c}$ as one of three diagnostic criteria for diabetes, respectively [2,3].

The glycosylation of hemoglobin occurs via a sequential two-step non-enzymatic reaction. Firstly, the neutral amino groups from $\mathrm{N}$-terminal residues or from the side chain of Lys residues in hemoglobin $(\mathrm{Hb})$ interact with the aldehyde or ketone groups in sugar molecules to form reversible Schiff base intermediates. Then the intermediate undergoes an irreversible intermolecular Amadori rearrangement to generate a more stable ketoamine structure [4]. The probabilities of glycosylation are dependent on the local pKa of the amino groups as well as the charge and steric effects by neighboring residues [5]. In general, the $\mathrm{pKa}$ values of $\alpha$-amino groups of $\mathrm{N}$-terminal residues, especially the one of $\beta$ Val 1 (close to 7), are lower than those of $\varepsilon$-amino groups of Lys residues in $\mathrm{Hb}$. In addition, a positively charged cavity around the $\beta$ Val1 moiety has a strong affinity to attract sugar molecules. Due to the high concentration of glucose in the blood stream, the most abundant form of the glycosylated hemoglobins (GHbs) is the glucose adduct named $\mathrm{HbA1c}$.

The $\mathrm{HbA} 1 \mathrm{c}$ level is defined as the ratio of $\mathrm{HbA} 1 \mathrm{c}$ to the total $\mathrm{Hb}$ concentration, and the physiological range of $\mathrm{HbA} 1 \mathrm{c}$ in the whole-blood samples is $3-13 \mathrm{mg} / \mathrm{mL}$ in terms of concentration or $5 \%$ to $20 \%$ in terms of percentage of total $\mathrm{Hb}$. The ADA-recommended diagnostic criteria of $\mathrm{HbA} 1 \mathrm{c}$ 
for diabetes and prediabetes are shown in Table 1 [6]. For pregnant diabetic individuals, it is strongly recommended that they have a stringent control on their $\mathrm{HbA} 1 \mathrm{c}$ to minimize risks such as congenital malformations, overweight infants, and complications of pregnancy [7]. Accurate and precise methods to detect $\mathrm{HbA} 1 \mathrm{c}$ are thus required for better diagnosis and management control of DM.

Table 1. ADA criteria for the diagnosis of diabetes and prediabetes based on $\mathrm{HbA1c}$.

\begin{tabular}{ccc}
\hline Status & HbA1c $(\%)^{\mathbf{a}}$ & HbA1c $_{(\mathbf{m m o l} / \mathbf{m o l})} \mathbf{b}$ \\
\hline Prediabetes & $5.7 \sim 6.4$ & $39 \sim 47$ \\
Diabetes & $\geq 6.5$ & $\geq 48$ \\
\hline \multicolumn{3}{c}{ a suggested by the Diabetes Control and Complications } \\
Trial (DCCT); ${ }^{\mathbf{b}}$ suggested by the IFCC.
\end{tabular}

In the past several decades, a variety of $\mathrm{HbA1c}$ detection methods has been developed, such as immunoassay [8], ion-exchange chromatography [9], boronate affinity chromatography [10], electrophoresis [11,12], and a colorimetric method [13]. Those methods can be generalized into three basic chemical principles based on charge differences, structural differences and chemical reactivity. Most of these methods are subject to at least one or more types of interferences from $\mathrm{Hb}$ variants including various forms of $\mathrm{Hb}(\mathrm{HbC}, \mathrm{HbS}, \mathrm{HbE}, \mathrm{HbD}$, and $\mathrm{HbF})$ and / or the modification of $\mathrm{Hb}$ (cabamylated $\mathrm{Hb}$, acetylated $\mathrm{Hb}$, labile $\mathrm{HbA1c}$ ) [14]. The global standardization of $\mathrm{HbA1c}$ was conducted by the IFCC and evaluated by different designated comparison methods developed by the National Glycohemoglobin Standardization Program (NGSP) and others, resulting in a laboratory-based gold reference method of $\mathrm{HbA1c}$ [15]. Although the IFCC reference method can provide precision and accuracy for $\mathrm{HbA1c}$ measurement [16], the needs for sophisticated equipment and the professional personnel to operate the system limit its accessibility to only large medical organizations or research institutions [17]. Therefore, it is valuable to develop methods that are easy to operate and cost-effective, but robust enough for clinical use. $\mathrm{HbA} 1 \mathrm{c}$ biosensors have great potential for the design of analytical devices with appropriate sensitivity, low cost, simplicity, and possibility for miniaturization. Recently, several very good review articles have summarized a wide range of methods being used for the determination of glycosylated proteins including $\mathrm{HbA1c}$ [18-23]. In this review, we summarize recent progress in the development of $\mathrm{HbA1c}$ biosensors from several aspects, including the prototypical methodology for $\mathrm{HbA1c}$ measurement, applications in whole-blood sample analysis, and the development of point-of-care (POC) technology in this research field, including non-invasive biosensors for diabetes.

\section{HbA1c Biosensors}

The recognition components of electrochemical $\mathrm{HbA} 1 \mathrm{c}$ biosensors can be divided into three categories: boronic acid derivatives, antibodies, and enzymes. This review will report on all three, below, and what follows here is a summary. Current progress on the most popular boronic acid-based electrochemical biosensors is summarized first, according to the type of boronic acid derivative employed, electrode-surface modification, and the detection method. Antibody-based immunobiosensors are mainly focused on immobilization of components, either $\mathrm{HbA} 1 \mathrm{c}$ or the $\mathrm{HbA1c}-$ specific antibody, and the subsequent detection of HbA1c. The working principle of the third type known as enzymatic reaction-based biosensors will be briefly introduced third.

\subsection{Affinity Biosensors Based on Boronic Acid Derivatives}

Boronic acid derivatives have a high affinity for the cis-diol group of the sugar moiety in glycosylated proteins, which is the fundamental principle behind several affinity-based methods for detection of glycosylated proteins including $\mathrm{HbA1c}$. Here we summarize the methods, which will be elaborated below. One way is to bind $\mathrm{Hbs}$ (both $\mathrm{HbA}$ and $\mathrm{HbA} 1 \mathrm{c}$ ) by haptoglobin (Hp) on an electrode surface first, and then ferrocene-boronic acid (FcBA) is added to the system. The FcBA, 
which can be probed by electrochemical signals, will interact with only $\mathrm{HbA1c}$, not $\mathrm{Hb}$, (Figure 1A). The second method is to immobilize boronic acid derivatives on the electrode, resulting in a selective binding of $\mathrm{HbA1c}$, by which an appropriate electrical signal can be detected (Figure 1B,C).

\subsubsection{Biosensors Based on Ferrocene-Boronic Acid (FcBA)}

FcBA plays a dual role in the determination of HbA1c. First, the boronic acid portion of the molecule interacts with $\mathrm{HbA1c}$. Second, the ferrocene portion is a redox-active label, therefore, it can be utilized for both target recognition and signal production. By using a pyrolytic graphite electrode (PGE), that is coated with zirconium dioxide $\left(\mathrm{ZrO}_{2}\right)$ nanoparticles (NP)/didodecyldimethyl-ammonium bromide (DDAB) interface, Liu et al first immobilized $\mathrm{Hbs}$ on the electrode, and then incubated the protein-bound electrode in FcBA solution. The binding of the FcBA to HbA1c generates a clear redox peak monitored by cyclic voltammetry, and the peak current of the bound FcBA increases linearly with $\mathrm{HbA} 1 \mathrm{c}$ levels in the range of 6.8 14\% [24]. However, the adsorption of $\mathrm{Hbs}$ onto $\mathrm{ZrO}_{2} / \mathrm{DDAB}$ interface is time-consuming and the statistical deviation of the method is relatively high by a comparison with the results measured by the reference method. Further improvement is required in terms of the response time and precision for the clinical application.

Halámek and coworkers tested various Hbs-adsorbent materials including surfactants, a strong cation propidium modifier, an organophosphorous compound and $\mathrm{Hp}$ as well. The deoxycholic acid (DOCA)-modified surface showed the best overall performance based on three parameters: loading capacity of the modifier, reproducibility of the piezoelectric sensor and the direct $\mathrm{Hb}$ reduction. The total $\mathrm{Hb}$ content deposited on the surface was monitored using a quartz crystal microbalance (QCM), while the $\mathrm{HbA} 1 \mathrm{c}$ concentration was obtained by subsequent voltammetric detection of FcBA coupled on the sensor surface, in which the signal is proportional to the HbA1c concentration [25]. Due to the heat-denaturation of the $\mathrm{Hb}$ pretreatment and a $\mathrm{pH}$-dependent high standard deviation value of the method, currently, this is still a HbA1c-assay concept.

Recently, quite a few of boronic acid-based biosensors have been developed for the capture and determination of $\mathrm{HbA} 1 \mathrm{c}$ including 3-aminophenylboronic acid (APBA), thiophene-3-boronic acid (T3BA), and formylphenylboronic acid (FPBA), as summarized in Table 2. In order to attach boronic acids to the electrode surface, one must modify them with cross-linking agents. For example, the electrodes can be modified with the cysteamine self-assembled monolayer (SAM), followed by glutaraldehyde and then APBA [26], to create the final boronate affinity layer (Figure 1C). There are other functions of cross-linking agents such as the ERGO-PQQ, ESM-glutaraldehyde, carboxy-EG6-undecanethiol and pTTBA-Au NPs used for the same purpose.

(A)

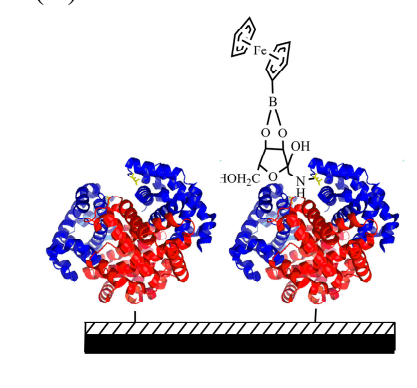

(B)

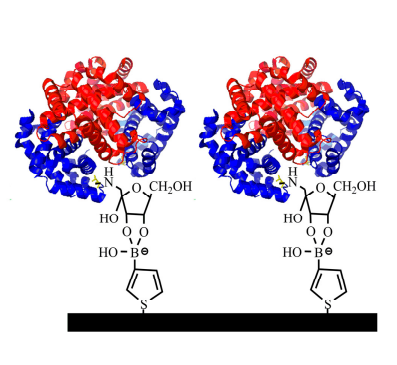

(C)
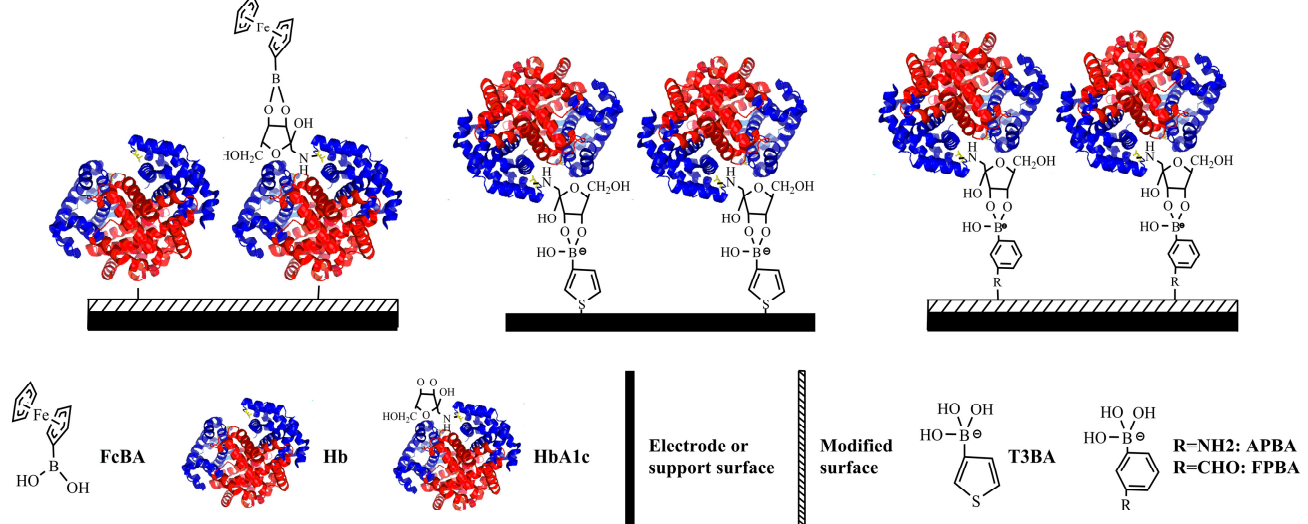

Figure 1. Schematic illustration of construction of boronic acid-based HbA1c sensors by using (A) FcBA; (B) T3BA; and (C) APBA or FPBA for HbA1c recognition. 


\subsubsection{Biosensors Based on Thiophene-3-Boronic Acid (T3BA)}

Electrochemical impedance spectroscopy (EIS) has been widely used to characterize sequential chemical modifications on an electrode surface by measuring changes of conductivity or dielectric constant, and can be adopted for the design of label-free biosensors. The instrument puts a small oscillating voltage across the membrane over a range of frequencies. The resulting current and its phase shift are the data that provide information about the interface. For example, T3BA-SAM is bound to the gold electrode surface via the Au-S covalent bonds (Figure 1B). The formation of T3BA-SAM followed by $\mathrm{HbA} 1 \mathrm{c}$ on the Au electrodes are confirmed and characterized by QCM, atomic force microscopy, and EIS methods [27]. The concentration of $\mathrm{HbA1c}$ on the T3BA-modified biosensors is measured by monitoring the changes of charge-transfer resistance, which are owed to the blocking of the electrode surface by the immobilized $\mathrm{HbA} 1 \mathrm{c}$, with hexacyanoferrate $(\mathrm{HCF})$ as the redox indicator $[27,28]$. Some sensors are developed to utilize the capacitive behaviors of the electrode interface to measure the surface-bound $\mathrm{HbA1} \mathrm{c}$ without a need of redox indicator [29]. However, the dynamic detection range of this method is yet to match the physiological range of $\mathrm{HbA1c}$ from 3 to $13 \mathrm{mg} / \mathrm{mL}$.

\subsubsection{Biosensors Based on 3-Aminophenyl Boronic Acid (APBA)}

Siva and coworkers reported the synthesis of a APBA-graphene oxide (GO) conjugate via the amide linkage confirmed by IR spectroscopy [30], and its application in the determination of glycosylated hemoglobin $(\mathrm{GHb})$ by EIS. It appears that the high conductivity and wide surface area of GO enhance the performance of these APBA-GO modified biosensors.

Eggshell membranes (ESMs), a natural porous fiber, are used as a low-cost protein-immobilization platform. By using 3-APBA-modified ESMs biosensor, the HbA1c can be measured in a clinically relevant range $(2.3 \sim 14 \%)$ with a detection limit of $0.19 \%$ [31]. The EIS biosensors exhibit good reproducibility, precision and selectivity. Although further optimization shortens the time of $\mathrm{HbA1c}$ measurement [32], the need for sophisticated instrumentation severely limits the EIS-based biosensor from being used for clinical application. In contrast, the features of simplicity and rapid measurement increase the possibility of the amperometric method for the design of portable devices.

Since the boronate-based biosensors lack selectivity between glycated $\mathrm{Hb}$ and sugar molecules, one can solve this by use of the heme iron as catalyst as well as by carrying out an adequate pretreatment of the sample to remove plasma interferences. Kim and coworkers have fabricated a disposable biosensor using APBA chemically bonded to a poly(terthiophenebenzoic acid) (pTTBA)/AuNPs-modified screen-printed electrode [33] (Figure 1C). The detection of HbA1c is by measurement of the response current of catalytic reduction $\mathrm{H}_{2} \mathrm{O}_{2}$ by the heme of the protein on the interface. The sensor has been used successfully for the analysis of simple filtration-prepared finger-prick blood samples, exhibiting a linear response to $\mathrm{HbA} 1 \mathrm{c}$ levels of $0.1 \sim 1.5 \%$ in amperometric mode and $0.5 \sim 6 \%$ in impedometric mode, respectively. An indirect competitive assay for $\mathrm{HbA} 1 \mathrm{c}$ determination was developed in which $\mathrm{HbA1c}$ competes with alizarin red S (ARS) for binding to phenylboronic acid (PBA) to form diol-boronic complexes in solution [34]. The potential shift of ARS is correlated with the competitive binding of $\mathrm{HbA} 1 \mathrm{c}$ to $\mathrm{PBA}$, and is proportional to the concentration of $\mathrm{HbA} 1 \mathrm{c}$. In addition, the total $\mathrm{Hb}$ concentration is measured using $\mathrm{HCF}$ as the redox indicator to give the result of $\% \mathrm{HbA} 1 \mathrm{c}$ in line with that measured by a reference method.

Although the above methods can provide direct electrochemical detection of $\mathrm{HbA} 1 \mathrm{c}$, they require addition of an exogenous redox indicator, such as a redox mediator or $\mathrm{H}_{2} \mathrm{O}_{2}$, due to the relative electrochemical inactivity of $\mathrm{HbA1c}$ itself. A label-free and enzyme-free $\mathrm{HbA1c}$ sensor was prepared by modifying the electrode surface with poly(3-aminophenylboronic acid) (PAPBA) NPs [35]. The peak current measured by differential pulse voltammogram (DPV) decreases with increasing HbA1c concentrations from 1.0 to $156 \mu \mathrm{M}$, owing to the fact that the $\mathrm{HbA} 1 \mathrm{c}$ bonded with the PAPBA interface blocks the ion-flux-channel of the PAPBA NPs. The sensor also showed high selectivity toward $\mathrm{HbA1c}$ over glucose, serum albumin, ascorbic acid, uric acid, dopamine and $\mathrm{Hb}$. A label-free voltammetric $\mathrm{HbA1c}$ sensor was fabricated by a composite multilayer of APBA-pyrroloquinoline 
quinone (PQQ) coupled with electrodeposition of reduced graphene oxide (ERGO) on the glassy carbon electrode (GCE) [36]. The APBA/PQQ/ERGO/GCE not only displays a high sensitivity for $\mathrm{HbA1c}$ determination with the linear range is $9.4 \sim 65.8 \mu \mathrm{g} / \mathrm{mL}$, but also can be applied for whole blood samples.

Besides the conventional electrochemical detection methods, Chen and coworkers also employed a home-built surface plasmon resonance (SPR) biosensor to study interactions between the APBA monolayer and $\mathrm{HbA} 1 \mathrm{c}$ as functions of $\mathrm{pHs}$ and salt concentrations [37]. The surface of an Au-coated SPR probe was modified with 4,4-dithiodibutyric acid (DTBA)-APBA monolayers in order to bind $\mathrm{HbA1c}$. Under the optimized condition, the SPR signal shows a linear response to $\mathrm{HbA} 1 \mathrm{c}$ in the range of $0.43-3.49 \mu \mathrm{g} / \mathrm{mL}$ and with the detection limit of $0.01 \mu \mathrm{g} / \mathrm{mL}$.

Table 2. Comparison of HbA1c biosensors based on boronic acid derivatives.

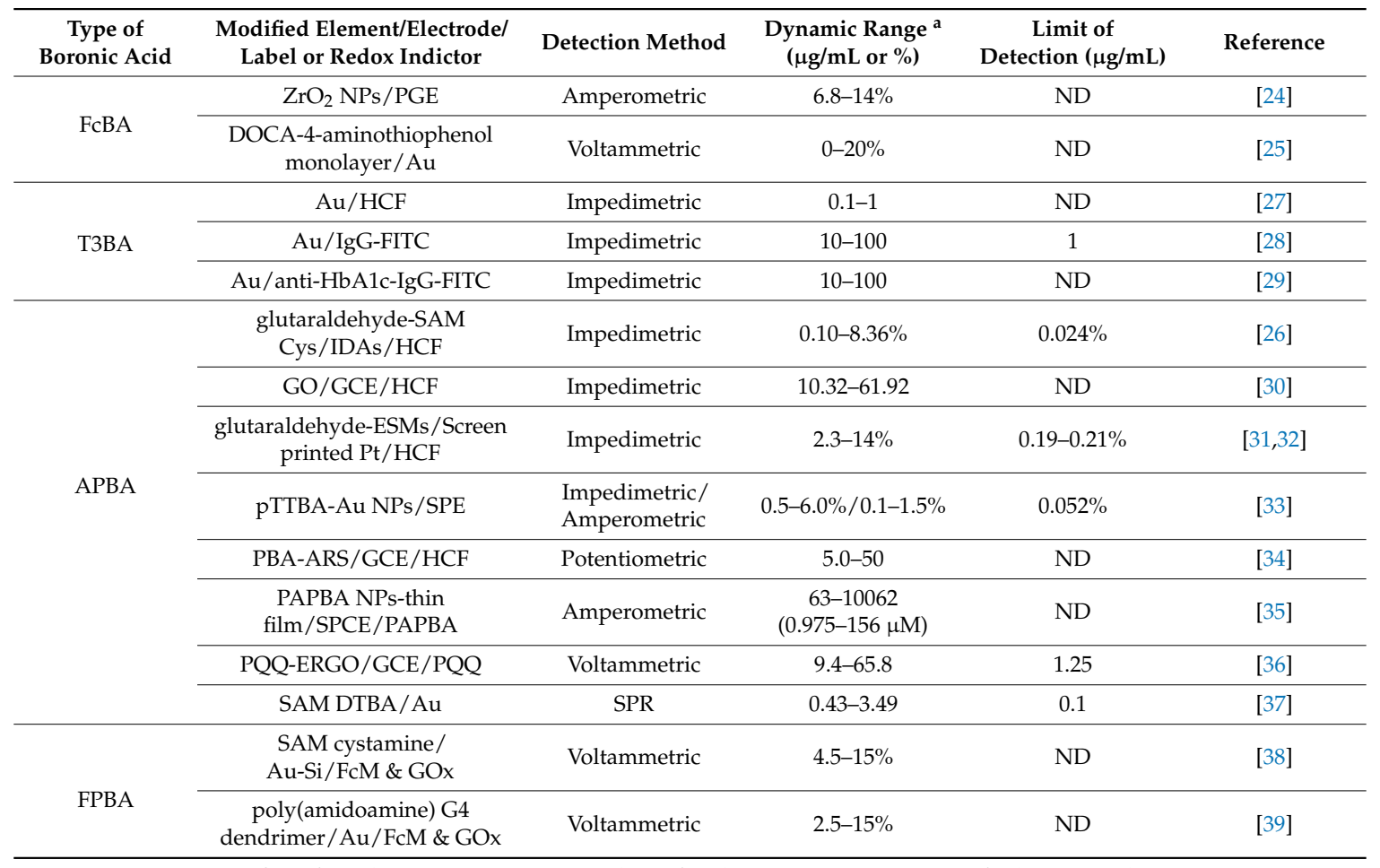

${ }^{\mathrm{a}} \mu \mathrm{g} / \mathrm{mL}$ for $\mathrm{HbA} 1 \mathrm{c}$ concentration only, $\%$ for the concentration ratio of $\mathrm{HbA} 1 \mathrm{c}$ to $\mathrm{HbA}$.

\subsubsection{Biosensors Based on Formylphenylboronic Acid (FPBA)}

More recently, to amplify the electrochemical signal, Song and coworkers developed a competitive binding assay, also named as an enzymatic backfilling assay, in which $\mathrm{HbA1c}$ is immobilized on a FPBA-modified interface first, then a known amount of glucose oxidase (GOx) is backfilled on the surface. Due to the reverse concentration correlation between $\mathrm{HbA} 1 \mathrm{c}$ and GOx, the electrochemical signal of the GOx decreases with the increasing $\mathrm{HbA1c}$ level [38,39]. In their early work, poly(amidoamine) G4 dendrimer was used as the interface material to capture periodate-activated GOx, and the current of GOx decreases with increasing $\mathrm{HbA1c}$ level from $2.5 \%$ to $15 \%$ with a spiking method. In 2012, the cystamine-FPBA conjugate was used to functionalize a gold electrode surface in order to bind $\mathrm{HbA} 1 \mathrm{c}$ and GOx competitively via cis-diol interaction. This method is applied for the $\mathrm{HbA1c}$ detection from whole blood samples. The pretreatment of $\mathrm{Hbs}$ via a $\mathrm{Zn}$-induced precipitation with a follow-up washing-out step was carried out to remove interference of other glycoproteins or carbohydrates in whole blood. The HbA1c-GOx competitive binding assay on a cystamine-FPBA/Au electrode could measure $\mathrm{HbA} 1 \mathrm{c}$ level in the range of $4.5 \sim 15 \%$ which covers the clinical reference range of diabetes without a need for detection labels. 


\subsection{Antibody-Modified Biosensors}

Immunobiosensors based on the different immobilization components can be divided into three categories. One is similar to the Fc-modified electrode, where $\mathrm{Hb}$ and $\mathrm{HbA1c}$ are immobilized on the surface of an electrode without differentiation (as Figure 2A). The second type is to attach $\mathrm{HbA} 1 \mathrm{c}$ analog on the electrode surface (as Figure 2B), which competes with $\mathrm{HbA1c}$ for the sites of $\mathrm{HbA1c}$-specific antibody. The third type is a fixed antibody as the recognition and capturing element for $\mathrm{HbA} 1 \mathrm{c}$ only (as Figure 2C). Comparison of determination features of $\mathrm{HbA1c}$ immunosensors based on the immobilization method is summarized in Table 3.

(A)
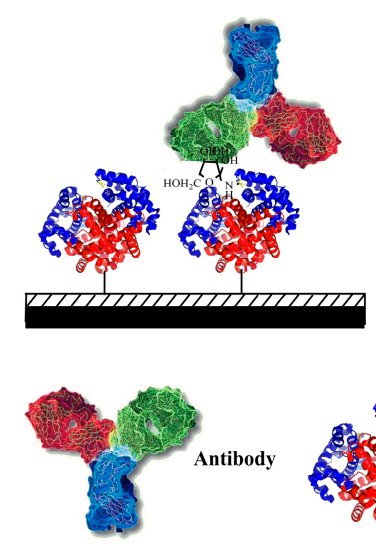

(B)
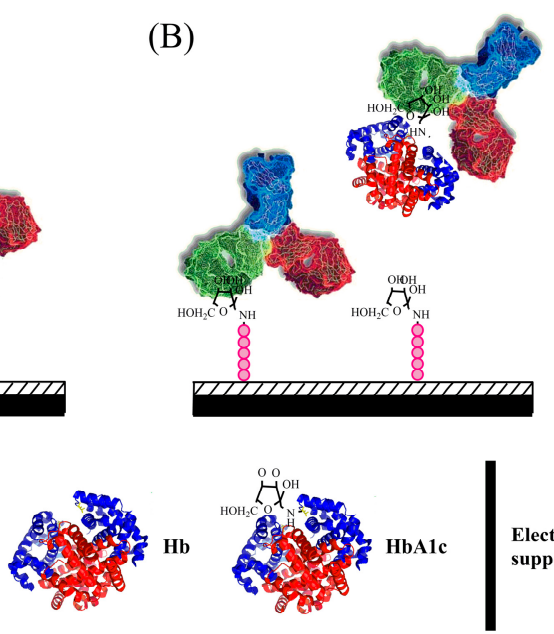

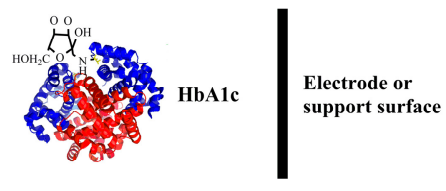

(C)
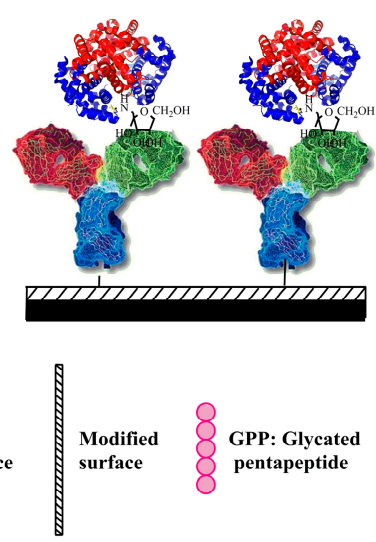

Figure 2. Schematic illustration of construction of HbA1c immunosensor by using (A) DOCA or Hp; (B) GPP; and (C) 3-MPA, PPy-Au NPs, and Mixed SAMs for HbA1c recognition.

\subsubsection{Immobilization of Hbs on the Electrode Surface}

Based on the design of DOCA-modified interface for Hbs immobilization [25], Halámek utilized anti-HbA1c immunoglobin $\mathrm{G}$ (IgG) to selectively bind to $\mathrm{HbA1c}$ and used FcBA which binds to multiple sugar moieties on IgG (Figure 2A) to amplify the electrochemical signal of FcBA [40]. The anodic peak height of the square wave voltammograms of FcBA is proportional to the bound IgG-FcBA which is correlated to the HbA1c present on the surface. The sensitivity of this electrochemical immunosensor is three times than that of the FcBA-based $\mathrm{HbA1c}$ sensors without the antibody.

Stöllner and coworkers developed a sandwich-type $\mathrm{HbA1c}$ sensor consisting of the first layer of a site-directed $\mathrm{Hp}$-modified cellulose membrane for Hbs enrichment, after capturing the $\mathrm{Hbs}$, and sequential addition of an anti-HbA1c antibody followed by the introduction of anti-IgG(sheep)-GOx for the specific detection of bound $\mathrm{HbA1c}$ [41]. Both the optical signal generated by the HbA1c-sandwich ELISA assay and the electrochemical responses generated from the Hp/anti-HbA1c-GOx/Clark-type electrode provide a linear correlation in the clinically relevant range of $5 \sim 20 \% \mathrm{HbA} 1 \mathrm{c}$ of total $\mathrm{Hb}$. However, the current status of the $\mathrm{HbA1c}$-sandwich immunoassay is still as a proof-of-concept design owing to the defects that include a single usage per membrane, long detection time needed, and a large dilution factor of blood sample required (up to 15,000-fold dilution) to minimize the non-specific binding of Hbs [41].

\subsubsection{Immobilization of a Glycated Pentapeptide as HbA1c Analogon}

Similar to the ARS/PBS competitive inhibition assay mentioned in the boronic affinity section, an immunoenzymometric assay for $\mathrm{HbA1c}$ detection has been developed based on the competitive binding of the $\mathrm{HbA} 1 \mathrm{c}$ analyte and the surface-bound glycated pentapeptide (GPP) epitope to a known amount of anti-HbA1c antibody [42]. The enzymatic activity of glucose oxidase-antibody conjugate 
measured by absorbance spectroscopy is proportional to the amount of surface-bound anti-HbA1c antibody for GPP, but in an inverse relationship to HbA1c concentration. The synthetic GPP analogon shares the same amino acid sequence of the first five residues of the $\mathrm{N}$-terminal $\beta \mathrm{Hb}$. Compared to one time usage of the protein-modified cellulose membrane, the GPP-modified surface exhibits very good reproducibility and can be repetitively regenerated more than 20 times without loss of the binding affinity.

Liu and coworkers constructed a series of electrochemical immunosensors based on the competitive inhibition assay in which $\mathrm{HbA1c}$ competes with surface-bound GPP for binding to anti-HbA1c antibody. There are several key features of the electrode fabrication for those biosensors: (i) the GCE surface is coated with a mixed layer of oligo(phenylethynylene) molecular wire (MW) and oligo(ethylene glycerol) (OEG) [43] or with AuNP-diazonium salt modified interface [44,45]; (ii) in the amperometric immunosensor, the redox probe of 1,10-di(aminomethyl) ferrocene (FDMA) is covalently bound to the modified interface followed by the immobilization of GPP; (iii) $\mathrm{Ru}\left(\mathrm{NH}_{3}\right)_{6}{ }^{3+} / \mathrm{Ru}\left(\mathrm{NH}_{3}\right)_{6}{ }^{2+}$ redox couple is used in the EIS immunosensor based on AuNP-diazonium salt modified interface; (iv) the OEG molecules work as the insulator to prevent nonspecific protein binding on the electrode surface; (v) in the amperometric mode, the relative current increases with the increase of $\mathrm{HbA1c}$ concentration; (vi) in the impedenmetric mode, the change of electron transfer resistance shows an inverse linear correlation with the increase of $\mathrm{HbA1c}$ concentration in the sample. The dynamic range of $\mathrm{HbA} 1 \mathrm{c}$ detection of those three types of electrochemical immunosensor covers the physiological range of $\mathrm{HbA} 1 \mathrm{c}$ level from $4.5 \sim 15 \%$.

\subsubsection{Immobilization of $\mathrm{HbA1c}$ Antibody}

The immobilization of the anti-HbA1c antibody on the electrode surface is the most direct and specific way to bind $\mathrm{HbA1c}$ (Figure 2C). By covalently immobilizing HbA1c-specific antibody on the surface of a gold working electrode treated with the SAM of 3-Mercaptopropionic acid (MPA), the binding of $\mathrm{HbA1c}$ was monitored by differential pulse voltammetry (DPV) using ferricyanide/ferrocyanide as the redox mediator [46]. The single-use disposable three-electrode immunosensor shows a linear range of $7.5-20 \mu \mathrm{g} / \mathrm{mL}$ of $\mathrm{HbA} 1 \mathrm{c}$ in $0.1 \mathrm{M}$ phosphate buffer solution and $0.1-0.25 \mathrm{mg} / \mathrm{mL}$ of $\mathrm{HbA} 1 \mathrm{c}$ in undiluted human serum. Hence, this biosensor has a great potential for application to in vitro measurement of $\mathrm{HbA1c}$ for diabetic management.

Xia and co-workers constructed a series of ion-sensitive field effect transistor (ISFET)-based HbA1c immunosensors composed of a FET-based sensor chip and a disposable extended-gate electrode chip by using complementary metal-oxide-semiconductor transistor (CMOS) and micro-electronic mechanical system (MEMS) techniques. Much effort has put on the method development of $\mathrm{HbA1c} / \mathrm{Hb}$ antibody immobilization on the gold working electrode, including polypyrrole (PPy)-Au NPs composite film [47], mixed self-assembled monolayers (SAMs), seed mediated growth of nanogold film [48], and mixed SAMs wrapped with a nanogold array [49-52]. The PPy-Au NPs composite gold electrode fabricated by electro-polymerization technique exhibits a linear response over $4 \sim 18 \mu \mathrm{g} / \mathrm{mL}$ of $\mathrm{HbA1c}$ [47]. Although the response time is fast (less than $1 \mathrm{~min}$ ), the stability and signal reproducibility of the sensor need further improvement.

The mixed SAMs wrapped with nano-gold array interface for antibody immobilization are prepared as follows: (i) form two-layer thiol-containing SAMs (16- and 3-mercaptohexadecanoic acid) on the gold nanospheres; (ii) modify the gold electrode with SAM of mercaptoethylamine; (iii) bioconjugate the mixed SAMs / Au nano-spheres with modified-Au electrode in the presence of NHS and EDC; (iv) and covalently bind the $\mathrm{HbA1}$ cor $\mathrm{Hb}$ antibodies on the mixed SAMs / Au electrode via the amide linkage in the presence of NHS and EDC.

The mixed SAMs/Au nanospheres array-modified electrode provides several valuable features. For example, the two-layer structure of SAMs on Au nano-spheres reduces the steric hindrance for biomolecule binding. Given the uniformly distribution of nano-spheres on the electrode surface with an increased large surface area-to-volume ratio, the sensitivity and signal reproducibility of this micro 
immunosensor are improved. In addition, by immobilizing $\mathrm{HbA} 1 \mathrm{c}$ and $\mathrm{HbA}$ antibody separately, the FET-based immunosensors can simultaneously measure $\mathrm{HbA} 1 \mathrm{c}$ and $\mathrm{HbA}$ concentrations without a separation procedure which has great advantages for the development of $\mathrm{HbA1c} P O C$ device.

A sandwich immunoassay configuration is constructed by using specific monoclonal $\mathrm{HbA}_{1 \mathrm{c}}$ antibody to capture the antigen followed with the addition of high fluorescent CdTe quantum dots (QDs)-labeled polyclonal secondary antibodies to measure $\mathrm{HbA1c}$ by both optical and electrochemical means [53]. The QD-based electrochemical assay showed a linear increase in current with increasing levels of $\mathrm{HbA1c}(4-16 \%)$ and a high correlation coefficient of $96 \%$ compared to that of the standardized HPLC method. Furthermore, this method requires a very small sample volume and is applicable for rapid, reproducible, and cost-effective analysis of $\mathrm{HbA1c}$ in clinical samples.

Table 3. Comparison of $\mathrm{HbA} 1 \mathrm{c}$ immunosensors based on recognition methods.

\begin{tabular}{|c|c|c|c|c|}
\hline Types & $\begin{array}{l}\text { Modified Element/Electrode/ } \\
\text { Label or Redox Indictor }\end{array}$ & Detection Method & $\begin{array}{c}\text { Dymamic } \\
\text { Range }(\mu \mathrm{g} / \mathrm{mL})\end{array}$ & Reference \\
\hline & $\mathrm{DOCA} / \mathrm{Au} / \mathrm{FcBA}$ & Voltammetric & ND & [40] \\
\hline Immobilized $\mathrm{Hbs}$ & $\begin{array}{c}\mathrm{Hp} / \text { cellulose membrane or } \\
\text { microtiter/TMB \& anti IgG-GOx }\end{array}$ & Amperometric & $0-25 \%(7.8-39 \mathrm{nM})$ & {$[41]$} \\
\hline \multirow{4}{*}{ Competitive inhibition } & $\begin{array}{l}\text { GPP/microtiter plate/ } \\
\text { TMB \& anti IgG-GOx }\end{array}$ & Photometric & $1.5-10(1 \mathrm{nM})$ & [42] \\
\hline & $\begin{array}{c}\text { Oligo(phenylethynylene) } \\
\text { MW-FDMA-GPP/GC/FDMA }\end{array}$ & Amperometric & $4.5-15.1 \%$ & [43] \\
\hline & Au NPs -FDMA-GPP/GCE/FDMA & Amperometric & $4.6-15.1 \%$ & [44] \\
\hline & $\mathrm{Au} \mathrm{NPs}-\mathrm{GPP} / \mathrm{GCE} / \mathrm{Ru}\left(\mathrm{NH}_{3}\right)_{6}{ }^{3+/ 2+}$ & Impedimetric & $0-23.3 \%$ & {$[45]$} \\
\hline \multirow{7}{*}{$\begin{array}{c}\text { Immobilized } \\
\text { anti-HbA1c Antibody }\end{array}$} & SAM 3-MPA/Au/HCF & Voltammetric & $7.5-20$ & [46] \\
\hline & Ppy-Au NPs /Au/PPy & Potentiometric & $4-18$ & [47] \\
\hline & $\begin{array}{l}\text { SAM 1,6-hexanedithiol Au } \\
\text { NPs / Au/HCF }\end{array}$ & Potentiometric & $4-24$ & [48] \\
\hline & mixed SAMs/Au/HCF & Potentiometric & ND & [49] \\
\hline & $\begin{array}{c}\text { mixed SAMs wrapped nano-spheres } \\
\text { array/Au/HCF }\end{array}$ & Potentiometric & $0.050-0.1705$ & [49-52] \\
\hline & $\begin{array}{l}\text { seed mediated growth } \\
\text { nano-gold/Au/HCF }\end{array}$ & Potentiometric & $0.00167-0.07214$ & [52] \\
\hline & $\begin{array}{l}\text { Protein A/laser ablated Au } \\
\text { electrode/anti HbA1c-QDs }\end{array}$ & Optic-electrochemical & ND & [53] \\
\hline
\end{tabular}

\subsection{Indirect HbA1c Biosensors Based on the Determination of Fructosyl Valine}

$\mathrm{HbA1c}$ can be potentially digested to form fructosyl valine (FV) moiety, which can be measured quantitatively via an enzymatic reaction by fructosyl amino acid oxidase (FAO). There are three categories of FV-based biosensors of which applications are summarized in Table 4.

Table 4. Comparison of FV sensors based on different oxidation methods.

\begin{tabular}{|c|c|c|c|c|c|c|}
\hline Type & $\begin{array}{l}\text { Modified Element/Electrode/ } \\
\text { Label or Redox Indictor }\end{array}$ & Detection Method & $\begin{array}{c}\text { Dynamic } \\
\text { Range (mM) }\end{array}$ & $\begin{array}{c}\text { Limit of } \\
\text { Detection (uM) }\end{array}$ & $\begin{array}{c}\text { Applied } \\
\text { Potient (V) }\end{array}$ & Reference \\
\hline \multirow{5}{*}{ Immobilized FAO } & PVA-SbQ/Pt & Amperometric & $0.2-10$ & 200 & 0.6 & [54] \\
\hline & Ir NPs/Carbon & Amperometric & $0-0.5$ & ND & 0.25 & [55] \\
\hline & $\mathrm{Fe}_{3} \mathrm{O}_{4} \mathrm{NPs} / \mathrm{Au} / \mathrm{HCF}$ & Amperometric & $0.1-2$ & 100 & ND & [56] \\
\hline & ZnO NPs-Ppy/Au/HCF & Amperometric & $0.1-3$ & 100 & ND & [57] \\
\hline & $\begin{array}{l}\text { Au NPs-GNs/ } \\
\text { FTO Glass Plate }\end{array}$ & Impedimetric & $0.0003-2.0$ & 0.2 & 0.2 & [58] \\
\hline \multirow{5}{*}{ MIC } & $\mathrm{PVI} / \mathrm{CPE} / \mathrm{m}-\mathrm{PMS}$ & Amperometric & $0.02-0.7$ & 20 & 0.1 & [59] \\
\hline & $\mathrm{MIC} / \mathrm{CPE} / \mathrm{m}-\mathrm{PMS}$ & Amperometric & $0.2-0.8$ & ND & ND & [60] \\
\hline & MIC-Allylamine/ND/m-PMS & Amperometric & ND & ND & 0.1 & [61] \\
\hline & $\mathrm{MIC} / \mathrm{Au} / \mathrm{m}-\mathrm{PMS}$ & Amperometric & $0.05-0.6$ & ND & ND & [62] \\
\hline & MIP & Thermometric & $0.25-5.0$ & ND & ND & [63] \\
\hline \multirow{2}{*}{ Non enzymatic } & None/GCPE/ITO glass & Amperometric & $0-1.0$ & ND & 1 & [64] \\
\hline & None/GCE/FcBA & Amperometric & $0.1-4.0$ & 500 & 0.1 & [65] \\
\hline
\end{tabular}


The first type of indirect $\mathrm{HbA1c}$ sensors measures the electro-oxidation of FV by FAO which is immobilized on the electrode surface prior to the enzymatic reaction (Figure $3 \mathrm{~A}$ ). The second category involves construction of a molecular-imprinted polymer (MIP) as the artificial enzyme to oxidize the FV (Figure 3B). The third type is to direct measure the oxidation of FV using electrochemical sensors (Figure 3C).

(A)

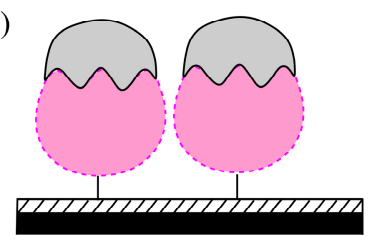

(B)

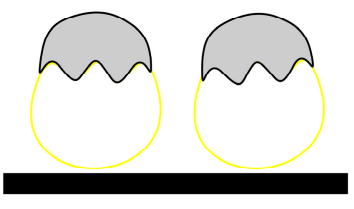

MIC
(C)

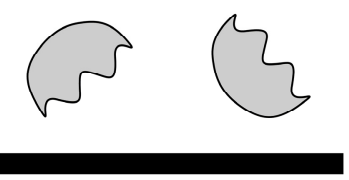

苜 $\begin{aligned} & \text { Modified } \\ & \text { surface }\end{aligned}$

Figure 3. Schematic illustration of the construction of indirect $\mathrm{HbA1c}$ biosensors based on the recognition of fructosyl valine on the (A) PVA-SbQ or NPs modified electrode surface; (B) by MIC method; (C) by Non-enzymatic method.

\subsubsection{Fructosyl Amino Acid Oxidase (FAO)-Modified Biosensors}

For the FAO-based biosensors, the enzyme can be either confined in the film made of poly(vinyl alcohol) cross-linked photochemically with stilbazole (PVA-SbQ) [54], or immobilized on the surface of nanoparticulate materials, such as iridium (Ir) NPs [55], $\mathrm{Fe}_{3} \mathrm{O}_{4} \mathrm{NPs}$ [56], ZnO NPs [57], and Au NPs [58]. The NPs, PPy, and graphene nanosheet are promising materials to be used for the fabrication of the FAO-modified biosensors.

The FAO enzyme can react with both FV and $\varepsilon$-fructosyl lysine ( $\varepsilon$-FL) substrates. This latter reaction would give a false positive, so it is not an ideal element for $\mathrm{HbA} 1 \mathrm{c}$ enzyme-based biosensors. Sakaguchi and coworkers used a novel protein, fructosyl amino acid binding protein, to detect FV [66]. Its high sensitivity and specificity for FV over $\varepsilon$-FL makes the new sensing system ideally suited for the measurement of $\mathrm{HbA1c}$. In addition, the protein engineering of FAOx was recently reviewed [67]. The FAO enzyme is still very expensive, and to obtain the FV will inevitably increase the cost and inconvenience for $\mathrm{HbA} 1 \mathrm{c}$ assays.

\subsubsection{Molecular Imprinting Catalyst (MIC)-Modified Biosensors}

Sode and coworkers constructed a MIC-based sensor using the molecular imprinting technology to create an artificial enzyme [60]. The MIC has a low selectivity to FV, so it is important to improve it to increase its selectivity. In addition to optimizing experimental conditions, Sode also used allylamine to increase the selectivity for FV [61], but the selectivity is still too low for practical detection. Recently, Yamazaki modified the Au electrode with a synthetic soluble molecular imprinting polymers (MIPs) to FV recognition [62]. Katterle and coworkers optimized the experiment by aligning PBA residues in a suitable orientation in MIPs for the binding of FV, resulting in a higher selectivity to FV compared to fructose and pinacol imprinting [68]. The same research group constructed a thermometric MIP sensor which can detect $\mathrm{FV}$ concentration in the range of $0.25-5 \mathrm{mM}$ [63].

\subsubsection{Non-Enzymatic Biosensors}

The FV concentration can also be measured in a non-enzymatic system. Chien and Chou constructed FcBA modified GCP electrode for both FV molecule recognition and electrochemical signal transduction [65]. The amperometric signal was linear for detection of FV concentrations at the $\mathrm{mM}$ level with negligible interference from glucose. The same authors tried to use a relatively high 
potential of $1.0 \mathrm{~V}$ to directly oxidize FV by a glassy carbon-paste electrode [64]. However, interfering compounds such as ascorbic acid could be oxidized at that potential and could give false readings.

\section{Analysis of Samples from Human Blood}

A good sensor system with potential for clinical use must be able to assess $\mathrm{HbA1c}$ level with the sensitivity and reproducibility while provide excellent operational and reagent-storage stability. The sensor system should be able to distinguish $\mathrm{HbA} 1 \mathrm{c}$ from non-glycated hemoglobin $(\mathrm{HbA} 0)$ or other interferences and demonstrate excellent agreement with a standard analytical method. Table 5 summarizes some the applications of biosensors in $\mathrm{HbA} 1 \mathrm{c}$ measurement from whole-blood samples.

Table 5. HbA1c biosensors for whole blood sample measurement.

\begin{tabular}{|c|c|c|c|c|c|c|}
\hline \multicolumn{3}{|c|}{ Biosensors } & \multirow{2}{*}{$\begin{array}{c}\text { Detection Method } \\
\text { HbA1c/HbA0 }\end{array}$} & \multicolumn{2}{|c|}{ Dynamic Range ( $\mu \mathrm{g} / \mathrm{mL})$} & \multirow{2}{*}{ Ref. } \\
\hline HbA1c/HbA0 & Electrode & Label/Redox Indictor & & HbA1c & HbA0 & \\
\hline ESMs-APBA/Hp-ESMs & SPCE & $\mathrm{HCF}$ & Impedimetric & $2.3-14 \%$ & 5000-200,000 & [32] \\
\hline APBA-PQQ-ERGO/none & GC & PQQ & $\begin{array}{l}\text { Voltammetric/ } \\
\text { Photometric }\end{array}$ & $9.4-65.8$ & 92.5 & [36] \\
\hline $\begin{array}{l}\text { DOCA-4-aminothiophenol } \\
\text { monolayer/none }\end{array}$ & $\mathrm{Au}$ & $\mathrm{FcBA}$ or anti-HbA1c $\mathrm{Ab}$ & $\begin{array}{l}\text { Voltammetric/ } \\
\text { Piezoelectric }\end{array}$ & $0-20 \%$ & ND & {$[25,40]$} \\
\hline $\begin{array}{c}\text { mixed SAMs wrapped } \\
\text { nano-spheres } \\
\text { array-anti-HbA1c/ } \\
\text { anti-HbA0 Ab }\end{array}$ & FET & $\mathrm{HCF}$ & Potentiometric & $0.05-0.1705$ & $0.167-0.570$ & [51] \\
\hline $\begin{array}{l}\text { ABPA-mercaptoundecanoic } \\
\text { acid/none }\end{array}$ & $\mathrm{Au}$ & ND & $\begin{array}{l}\text { Piezoelectric/ } \\
\text { Photometric }\end{array}$ & $\begin{array}{c}3-11 \% \\
50-2000\end{array}$ & $10-90$ & [69] \\
\hline $\begin{array}{l}\text { m-APBA agarose } \\
\text { beads/none }\end{array}$ & IDAs & $\mathrm{HCF}$ & Electrochemical & ND & ND & [70] \\
\hline APBA-column/none & GC & Ferrocene/FC-Ab & Amperometric & $4-12.6 \%$ & $0-500$ & [71] \\
\hline APBA/sol-gel film & RVC/SPE & ND & Amperometric & $200-12,000$ & $20,000-200,000$ & [72] \\
\hline $\begin{array}{l}\text { carboxy-EG6-undecanethiol } \\
\text {-APBA/11-amino } \\
\text {-1-undecanethiol }\end{array}$ & $\mathrm{Au}$ & Luminol $/ \mathrm{H}_{2} \mathrm{O}_{2}$ & Chemiluminescence & $2.5-17 \% 2-80$ & 50-200 & [73] \\
\hline $\begin{array}{l}\text { MWCNT-pTTBA-TBO } \\
\text { \& aptamer/TBO }\end{array}$ & SPCE & TBO & Amperometric & $0.387-484$ & $6.45-645$ & [74] \\
\hline
\end{tabular}

Most of the examples described in the section above mainly focus on the method development for $\mathrm{HbA} 1 \mathrm{c}$ determination. For practical application, $\mathrm{HbA} 1 \mathrm{c}$ content rather than $\mathrm{HbA} 1 \mathrm{c}$ concentration is used, which is the ratio of $\mathrm{HbA}_{1 \mathrm{c}}$ concentration to total $\mathrm{Hb}$ concentration. Units for $\mathrm{HbA} 1 \mathrm{c}$ content are commonly reported either in $\mathrm{mmol} / \mathrm{mol}$ (used by the IFCC) or in percentage format (used by the NSGP). In general, a pretreatment of blood samples is needed to remove plasma interference followed by lysis of the RBCs. $\mathrm{Hb}$ and $\mathrm{HbA1c}$ are then measured separately using those biosensor systems.

An UV-Vis spectroscopy method can be used to quantify $\mathrm{Hb}$ concentration before the hemolysate sample is applied to biosensors for $\mathrm{HbA1c}$ readout [36]. The $\mathrm{HbA1c}$ content can easily be calculated from these numbers. However, this kind of detection method is inconvenient in practice because the detection and separation are distinct processes.

Halámek and coworkers have developed FcBA-based biosensors for the detection of $\mathrm{HbA} 1 \mathrm{c}[25,40]$. Hbs are adsorbed to the surfactant-modified surface first, and then followed by using the mass-sensitive quartz crystal balance, and also using voltammetry to monitor total $\mathrm{Hb}$ and $\mathrm{HbA} 1 \mathrm{c}$, respectively. $\mathrm{HbA} 1 \mathrm{c}$ binding to the APBA-modified electrodes was reversible, thereby providing a reusable sensing system. As such, Halámek applied the feature to develop a novel $\mathrm{HbA1c}$ biosensor based on flow injection [72]. They used a reticulated vitreous carbon (RVC) electrode modified with 3-APBA to separate and detect the $\mathrm{HbA1c}$ concentration, followed by the detection of $\mathrm{Hb}$ using the screen-printed electrode modified with a sol-gel film involving chitosan, and tetraenthoxyl silica entrapped into carbon nanotubes. This sensor showed a good relation between signal and Hbs concentrations. 
Even though gold has been commonly used in the biosensor system, carbon or membrane-based materials have been adopted into for their biocompatibility and cost effective feature. Booyasit constructed an 3-APBA-modified ESMs electrode to detect HbA1c and a Hp-modified ESMs electrode to determine the $\mathrm{Hb}$ [32]. These sensors can simultaneously detect total $\mathrm{Hb}$ and $\mathrm{HbA} 1 \mathrm{c}$ with excellent precision and also an acceptable reproducibility of fabrication. The chemical stability of the Hp-modified ESMs is good (98.84\% over a shelf-life of 4 weeks), however, for the APBA-modified ESMs, the stability is not so good ( $92.35 \%$ over a one-week period). Thus one needs to improve the stability of the APBA-modified ESM for clinical application.

In addition to the electrochemical signal transduction pathway, optical detection methods are also used in the $\mathrm{HbA1c}$ biosensor systems. Ahn and coworkers fabricated a $\mathrm{HbA1c}$-capturing interface made of carboxy-EG6-undecanethiol SAM coupled with 3-APBA on a gold thin-film substrate, and used an 11-amino-1-undecanethiol SAM modified gold substrate for $\mathrm{Hb}$ immobilization [73]. The chemical luminescence (CL) response in the Luminol $/ \mathrm{H}_{2} \mathrm{O}_{2}$ system in which the four heme groups play a role as the catalyst is linearly proportional to the amount of Hbs. The luminol CL method not only provides a high sensitivity for $\mathrm{HbA1c}$ detection without the need for signal amplification, but also can be used for $\mathrm{Hb}$ detection on an amino-SAM based interface, which means this method can be applied on whole blood sample analyses. The linear dynamic range of $\mathrm{HbA1c}$ level is from $2.5 \%$ to $17 \%$ which covers the clinical concentration range with negligible interference from other carbohydrates.

One of the main advantages of the boronate affinity-based method is that the measurement does not interfere with $\mathrm{Hb}$ variants such as $\mathrm{HbF}, \mathrm{HbS}, \mathrm{HbC}$, formayl- $\mathrm{Hb}$ etc., which makes it applicable to a large population. In addition, boronate-based reagents are relative stable and cost-effective compared to $\mathrm{HbA1c}$ antibodies. Due to the nature of the boron-cis-diol covalent bond, this method actually measures $\mathrm{GHb}$ (HbA1c and $\mathrm{Hb}$ glycated at other Lys sites) and also interferes with other endogenous sugar molecules in the sample.

Because of its high specificity and selectivity, the $\mathrm{HbA1c}$ antibody is the best candidate for capturing $\mathrm{HbA} 1 \mathrm{c}$. Xia and coworkers developed a micro immunosensor consisting of an ISFET integrated chip (see Section 2.2.3 above) and an electrode array based on the micro-electro-mechanical systems (MEMS) technology, modified with anti-Hb and anti-HbA1c antibodies [51]. The sensor can simultaneously detect the concentration of $\mathrm{HbA} 1 \mathrm{c}$ and $\mathrm{Hb}$ to obtain $\mathrm{HbA} 1 \mathrm{c}$ level. The responses of the immunosensor are linear over the concentration range of $166.7-570 \mathrm{ng} / \mathrm{ml} \mathrm{Hb}$ and $50 \sim 170.5 \mathrm{ng} / \mathrm{ml}$ $\mathrm{HbA1c}$ which are $10^{5}$-fold lower than physiological $\mathrm{Hb}$ concentrations. To apply the method for whole blood analysis, the samples were lysed and diluted 150,000-fold prior to measurements. This micro immunosensor exhibited a low relative deviation of measured $\mathrm{HbA} 1 \mathrm{c}$ level. By reducing cost, enhancing the shelf-life of the antibody, and invoking lab-on-a-chip (LOC) technology, electrochemical immunosensors will have a great potential to be translated into clinical use.

Moon and coworkers developed a disposable microfluidic amperometric dual-sensor for the detection of $\mathrm{HbA} 1 \mathrm{c}$ and total $\mathrm{Hb}$ separately [74]. The concentration of total $\mathrm{Hb}$ was measured by the cathodic currents of total Hb catalyzed by a TBO/pTTBA@MWCNT-modified working electrode. On the other surface of the dual-sensor, aptamer was used for HbA1c immobilization. After removal of unbound $\mathrm{Hb}$ by washing with $\mathrm{PBS}$, the cathodic current of $\mathrm{HbA1c}$ captured on the surface was determined by the aptamer/TBO/pTTBA@ MWCNT-modified working electrode in the fluidic channel.

Given the advantages of minimal sample volume, rapid analysis time and wide accessibility to diagnosis, the global POC diagnosis market is expected to reach US $\$ 36.93$ billion by 2021 (http:/ / www.marketsandmarkets.com/PressReleases/point-of-care-diagnostic.asp). More than a dozen commercial $\mathrm{HbA} 1 \mathrm{c}$ POC devices are currently used in clinics, of which the principal detection method is either based on boronate affinity separation or immunoassay. Among most cited devices, In2it $^{\text {TM }}$ (Bio-Rad, Hercules, CA, USA), Alere Afinion ${ }^{\mathrm{TM}}$ (Alere Technologies AS, Oslo, Norway), Nycocard (Alere Technologies AS) and Clover A1c (Inforpia, Kyunggi, Korea) are built based on the affinity method, while DCA Vantage (Siemens Medical Solutions Diagnostics, Tarrytown, NY, USA) 
and A1CNow series (Bayer HealthCare, Sunnyvale, CA, USA) are based on the immunoassay method. In a very recent review, Hirst and coworker independently reviewed 1739 records published before June 2015 in several databases (Medline, Embase and Web of Science) and carried out a meta-analysis on sixty-one studies to compare the accuracy and precision of eleven HbA1c POC devices [75]. The analysis results show that the majority of devices ( 9 out of 11) have a negative mean bias compared to laboratory comparator methods, as well as a large variability in bias within devices. The implication of using $\mathrm{HbA1c} P O C$ testing results on medical treatment decision-making and patient outcomes needs to be evaluated further.

\section{Conclusions}

With the number of diabetic patients increasing each year, it has caused a huge burden on public medical resources. A HbA1c POC device with good analytical performance can help patients with diabetes to monitor their long-term glycemic status. More importantly, the characteristics of immediate feedback can avoid delaying the diagnosis and treatment of diabetes. The boronate affinity-based method and the immunoassay method are the two methodologies currently used in commercially available $\mathrm{HbA1c}$ POC devices. Given the advantages of being relatively simple to operate, easy to miniaturize as well as its high sensitivity, the electrochemical $\mathrm{HbA} 1 \mathrm{c}$ biosensors can be potentially translated for clinical use.

Other noninvasive technologies have emerged to supplement current blood glucose and $\mathrm{HbA} 1 \mathrm{c}$ measurements for diabetes diagnosis and management. For example, Saraoglu developed a QCM sensor by an electronic breath-analysis system to detect the amount of acetone in exhaled breath for indirectly determining $\mathrm{HbA} 1 \mathrm{c}$ levels and blood glucose for 30 patients' samples [76]. The average accuracy rates for $\mathrm{HbA1c}$ level and blood glucose predictions are approximate $83 \%$ and $75 \%$, respectively. With an expected global market of up to US $\$ 12.2$ billion by the end of 2017, blood glucose monitoring occupies the top share in the POC market [77]. Raman scattering has also become a promising tool for noninvasive, continuous tracking of blood glucose level [78,79]. By exploiting an improved concentration independent calibration approach, Spegazzini and coworkers performed a longitudinal tracking of blood glucose which exhibited a 35\% reduction in error compared to a conventional calibration method [79].

The integrations of affinity- and immunoassay-based $\mathrm{HbA1c}$ biosensors with emerging cell phone-based technology and LOC platforms, supplemented by noninvasive blood glucose monitoring provide a highly promising interface for the design of new generation of personalized $\mathrm{HbA} 1 \mathrm{c}$ POC devices [77].

Acknowledgments: This work was supported by National Natural Science Foundation of China (Grant No. 21271104 and 21671103 for J. Yi). Thank Sackelia F. Willie for discussion.

Conflicts of Interest: The authors declare no conflicts of interest.

\section{Abbreviations}

$\begin{array}{ll}\text { ADA } & \text { American Diabetes Association } \\ \text { APBA } & \text { 3-aminophenyl boronic acid } \\ \text { ARS } & \text { alizarin red S } \\ \mathrm{Au} & \text { gold } \\ \text { CPE } & \text { carbon paste electrode } \\ \text { DCCT } & \text { Diabetes Control and Complications Trial } \\ \text { DDAB } & \text { didodecyl-dimethylammonium bromide } \\ \text { DM } & \text { diabetes mellitus } \\ \text { DOCA } & \text { deoxycholic acid } \\ \text { DTBA } & \text { 4,4-dithiodibutyric acid } \\ \text { EIS } & \text { electrochemical impedance spectroscopy } \\ \text { ERGO } & \text { electrodeposition of reduced graphene oxide }\end{array}$




\begin{tabular}{|c|c|}
\hline ESMs & eggshell membranes \\
\hline FAO & fructosyl amino acid oxidase \\
\hline FcBA & ferrocene-boronic acid \\
\hline $\mathrm{FcM}$ & ferrocenemethanol \\
\hline FDMA & 1,10-di(aminomethyl) ferrocene \\
\hline FET & field effect transistor \\
\hline FITC & fluorescein isothiocyanate \\
\hline FPBA & formyl-phenylboronic acid \\
\hline FTO & fluorine doped tin oxidase \\
\hline FV & fructosyl valine \\
\hline GCE & glassy carbon electrode \\
\hline GCPE & glassy carbon paste electrode \\
\hline GHbs & glycosylated hemoglobins \\
\hline GNs & graphene nanosheets \\
\hline GO & graphene oxide \\
\hline GOx & glucose oxidases \\
\hline GPP & glycated pentapeptide \\
\hline $\mathrm{Hb}$ & hemoglobin \\
\hline $\mathrm{HbA0}$ & non-glycated hemoglobin \\
\hline $\mathrm{HbA} 1 \mathrm{c}$ & glycated hemoglobin \\
\hline $\mathrm{HCF}$ & hexacyanoferrate \\
\hline $\mathrm{Hp}$ & haptoglobin \\
\hline IDA & interdigitated electrode array \\
\hline IFCC & $\begin{array}{l}\text { International Federation of Clinical Chemistry and } \\
\text { Laboratory Medicine }\end{array}$ \\
\hline IgG & immunoglobin G \\
\hline ISFET & ion-sensitive field-effect transistors \\
\hline ITO & indium tin oxide \\
\hline LOC & lab-on-a-chip \\
\hline LOD & limit of detection \\
\hline MEMS & micro-electro-mechanical systems \\
\hline MIC & molecular imprinting catalyst \\
\hline MIPs & molecular imprinting polymers \\
\hline MPA & 3-Mercaptopropionic acid \\
\hline MWCNT & multi-wall carbon nanotube \\
\hline NGSP & National Glycohemoglobin Standardization Program \\
\hline NPs & nanoparticles \\
\hline OEG & oligo(ethylene glycol) \\
\hline PAPBA & poly(3-aminophenylboronic acid) \\
\hline PGE & pyrolytic graphite electrode \\
\hline POC & point-of-care \\
\hline PPy & polypyrrole \\
\hline PQQ & pyrroloquinoline quinone \\
\hline pTTBA & poly $\left(2,2^{\prime}: 5^{\prime}, 5^{\prime \prime}\right.$-terthiophene-- $3^{\prime}$-p-benzoic acid) \\
\hline QDs & quantum dots \\
\hline RVC & reticulated vitreous carbon \\
\hline SAM & self-assembled monolayer \\
\hline SPCE & screen-printed carbon electrode \\
\hline SPE & screen-printed electrode \\
\hline SWV & square wave voltammograms \\
\hline T3BA & thiophene-3-boronic acid \\
\hline TBO & toluidine blue $\mathrm{O}$ \\
\hline TMB & 3,3',5,5'-tetramethylbenzidine \\
\hline WHO & World Health Organization \\
\hline $\mathrm{ZnO}$ & zinc oxide \\
\hline $\mathrm{ZrO}_{2}$ & zirconium dioxide \\
\hline
\end{tabular}




\section{References}

1. Ogurtsova, K.; da Rocha Fernandes, J.D.; Huang, Y.; Linnenkamp, U.; Guariguata, L.; Cho, N.H.; Cavan, D.; Shaw, J.E.; Makaroff, L.E. IDF Diabetes Atlas: Global estimates for the prevalence of diabetes for 2015 and 2040. Diabetes Res. Clin. Pract. 2017, 128, 40-50. [CrossRef] [PubMed]

2. American Diabetes Association. Diagnosis and classification of diabetes mellitus. Diabetes Care 2010, 33 , S62-S69.

3. World Health Organization. Use of Glycated Haemoglobin (HbA1c) in the Diagnosis of Diabetes Mellitus; World Health Organization: Geneva, Switzerland, 2011; pp. 1-25.

4. Bunn, H.F.; Haney, D.N.; Gabbay, K.H.; Gallop, P.M. Further identification of the nature and linkage of the carbohydrate in hemoglobin A1c. Biochem. Biophys. Res. Commun. 1975, 67, 103-109. [CrossRef]

5. Shapiro, R.; McManus, M.J.; Zalut, C.; Bunn, H.F. Sites of nonenzymatic glycosylation of human hemoglobin A. J. Biol. Chem. 1980, 255, 3120-3127. [CrossRef]

6. American Diabetes Association. Classification and diagnosis of diabetes. Diabetes Care 2017, 40, S11-S24.

7. Kitzmiller, J.L.; Block, J.M.; Brown, F.M.; Catalano, P.M.; Conway, D.L.; Coustan, D.R.; Gunderson, E.P.; Herman, W.H.; Hoffman, L.D.; Inturrisi, M.; et al. Managing preexisting diabetes for pregnancy: Summary of evidence and consensus recommendations for care. Diabetes Care 2008, 31, 1060-1079. [CrossRef] [PubMed]

8. Tanaka, T.; Matsunaga, T. Detection of $\mathrm{HbA}(1 \mathrm{c})$ by boronate affinity immunoassay using bacterial magnetic particles. Biosens. Bioelectron. 2001, 16, 1089-1094. [CrossRef]

9. Koskinen, L.K. Specificity of hemoglobin A1c measurement by cation exchange liquid chromatography. Evaluation of a Mono S column method. Clin. Chim. Acta 1996, 253, 159-169. [CrossRef]

10. Li, Y.; Jeppsson, J.-O.; Jornten-Karlsson, M.; Larsson, E.L.; Jungvid, H.; Galaev, I.Y.; Mattiasson, B. Application of shielding boronate affinity chromatography in the study of the glycation pattern of haemglobin. J. Chromatogr. B 2002, 776, 149-160. [CrossRef]

11. Koval, D.; Kasicka, V.; Cottet, H. Analysis of glycated hemoglobin A1c by capillary electrophoresis and capillary isoelectric focusing. Anal. Biochem. 2011, 413, 8-15. [CrossRef] [PubMed]

12. Marinova, M.; Altinier, S.; Caldini, A.; Passerini, G.; Pizzagalli, G.; Brogi, M.; Zaninotto, M.; Ceriotti, F.; Plebani, M. Multicenter evaluation of hemoglobin A1c assay on capillary electrophoresis. Clin. Chim. Acta 2013, 424, 207-211. [CrossRef] [PubMed]

13. Parker, K.M.; England, J.D.; Costa, J.D.; Hess, R.L.; and Goldstein, D.E. Improved colorimetric assay for glycasylated hemoglobin. Clin. Chem. 1981, 2715, 669-672.

14. Schnedl, W.J.; Krause, R.; Halwachs-Baumann, G.; Trinker, M.; Lipp, R.W.; Krejs, G.J. Evaluation of HbA1c determination methods in patients with hemoglobinopathies. Diabetes Care 2000, 23, 339-344. [CrossRef] [PubMed]

15. Jeppsson, J.O.; Kobold, U.; Barr, J.; Finke, A.; Hoelzel, W.; Hoshino, T.; Miedema, K.; Mosca, A.; Mauri, P.; Paroni, R.; et al. Approved IFCC reference method for the measurement of HbA1c in human blood. Clin. Chem. Lab. Med. 2002, 40, 78-89. [CrossRef] [PubMed]

16. Goodall, I. HbA1c standardisation destination-Global IFCC standardisation. How, why, where and when-A tortuous pathway from kit manufacturers, via inter-laboratory lyophilized and whole blood comparisons to designated national comparison schemes. Clin. Biochem. Rev. 2005, 26, 5-19. [PubMed]

17. Ang, S.H.; Thevarajah, M.; Alias, Y.; Khor, S.M. Current aspects in hemoglobin A1c detection: A review. Clin. Chim. Acta 2015, 439, 202-211. [CrossRef] [PubMed]

18. Wang, B.; Takahashi, S.; Du, X.; Anzai, J. Electrochemical biosensors based on ferroceneboronic acid and its derivatives: A review. Biosensors 2014, 4, 243-256. [CrossRef] [PubMed]

19. Yazdanpanah, S.; Rabiee, M.; Tahriri, M.; Abdolrahim, M.; Tayebi, L. Glycated hemoglobin-detection methods based on electrochemical biosensors. TrAC Trends Anal. Chem. 2015, 72, 53-67. [CrossRef]

20. Wang, B.; Anzai, J.-I. Recent progress in electrochemical HbA1c sensors: A review. Materials 2015, 8, 1187-1203. [CrossRef]

21. Anzai, J. Recent progress in electrochemical biosensors based on phenylboronic acid and derivatives. Mater. Sci. Eng. C Mater. Biol. Appl. 2016, 67, 737-746. [CrossRef] [PubMed]

22. Zhou, W.J.; Wu, Y.X.; Yi, J. Standardization and technology development of measurement of glycated human hemoglobin. Prog. Biochem. Biophys. 2015, 42, 443-456. 
23. Vashist, S.K.; Schleicher, E.; Luppa, P.B.; Luong, J.H.T. Glycated haemoglobin (HbA1c) monitoring for diabetes diagnosis, management and therapy. In Point-of-Care Glucose Detection for Diabetic Monitoring and Management; Vashist, S.K., Luong, J.H.T., Eds.; CRC Press: Boca Raton, FL, USA, 2016; pp. 97-124. ISBN 978-1-4987-8875-5.

24. Liu, S.; Wollenberger, U.; Katterle, M.; Scheller, F.W. Ferroceneboronic acid-based amperometric biosensor for glycated hemoglobin. Sens. Actuators B Chem. 2006, 113, 623-629. [CrossRef]

25. Halámek, J.; Wollenberger, U.; Stöcklein, W.; Scheller, F.W. Development of a biosensor for glycated hemoglobin. Electrochim. Acta 2007, 53, 1127-1133. [CrossRef]

26. Boonyasit, Y.; Laiwattanapaisal, W.; Chailapakul, O.; Emneus, J.; Heiskanen, A.R. Boronate-modified interdigitated electrode array for selective impedance-based sensing of glycated hemoglobin. Anal. Chem. 2016, 88, 9582-9589. [CrossRef] [PubMed]

27. Park, J.Y.; Chang, B.Y.; Nam, H.; Park, S.M. Selective electrochemical sensing of glycated hemoglobin $(\mathrm{HbA}(1 \mathrm{c}))$ on thiophene-3-boronic acid self-assembled monolayer covered gold electrodes. Anal. Chem. 2008, 80, 8035-8044. [CrossRef] [PubMed]

28. Hsieh, K.M.; Lan, K.C.; Hu, W.L.; Chen, M.K.; Jang, L.S.; Wang, M.H. Glycated hemoglobin (HbA1c) affinity biosensors with ring-shaped interdigital electrodes on impedance measurement. Biosens. Bioelectron. 2013, 49, 450-456. [CrossRef] [PubMed]

29. Chuang, Y.-C.; Lan, K.-C.; Hsieh, K.-M.; Jang, L.-S.; Chen, M.-K. Detection of glycated hemoglobin (HbA1c) based on impedance measurement with parallel electrodes integrated into a microfluidic device. Sens. Actuators B Chem. 2012, 171-172, 1222-1230. [CrossRef]

30. Krishna, S.R.; Bhat, N.; Amrutur, B. Detection of glycated hemoglobin using 3-aminophenylboronic acid modified graphene oxide. In Proceedings of the IEEE/NIH Life Science Systems and Applications Workshop (LiSSA), Bethesda, MD, USA, 7-8 April 2011.

31. Boonyasit, Y.; Heiskanen, A.; Chailapakul, O.; Laiwattanapaisal, W. Selective label-free electrochemical impedance measurement of glycated haemoglobin on 3-aminophenylboronic acid-modified eggshell membranes. Anal. Bioanal. Chem. 2015, 407, 5287-5297. [CrossRef] [PubMed]

32. Boonyasit, Y.; Chailapakul, O.; Laiwattanapaisal, W. A multiplexed three-dimensional paper-based electrochemical impedance device for simultaneous label-free affinity sensing of total and glycated haemoglobin: The potential of using a specific single-frequency value for analysis. Anal. Chim. Acta 2016, 936, 1-11. [CrossRef] [PubMed]

33. Kim, D.M.; Shim, Y.B. Disposable amperometric glycated hemoglobin sensor for the finger prick blood test. Anal. Chem. 2013, 85, 6536-6543. [CrossRef] [PubMed]

34. Liu, H.; Crooks, R.M. Determination of percent hemoglobin A1c using a potentiometric method. Anal. Chem. 2013, 85, 1834-1839. [CrossRef] [PubMed]

35. Wang, J.Y.; Chou, T.C.; Chen, L.C.; Ho, K.C. Using poly(3-aminophenylboronic acid) thin film with binding-induced ion flux blocking for amperometric detection of hemoglobin A1c. Biosens. Bioelectron. 2015, 63, 317-324. [CrossRef] [PubMed]

36. Zhou, Y.; Dong, H.; Liu, L.; Hao, Y.; Chang, Z.; Xu, M. Fabrication of electrochemical interface based on boronic acid-modified pyrroloquinoline quinine/reduced graphene oxide composites for voltammetric determination of glycated hemoglobin. Biosens. Bioelectron. 2015, 64, 442-448. [CrossRef] [PubMed]

37. Liu, J.T.; Chen, L.Y.; Shih, M.C.; Chang, Y.; Chen, W.Y. The investigation of recognition interaction between phenylboronate monolayer and glycated hemoglobin using surface plasmon resonance. Anal. Biochem. 2008, 375, 90-96. [CrossRef] [PubMed]

38. Song, S.Y.; Han, Y.D.; Park, Y.M.; Jeong, C.Y.; Yang, Y.J.; Kim, M.S.; Ku, Y.; Yoon, H.C. Bioelectrocatalytic detection of glycated hemoglobin (HbA1c) based on the competitive binding of target and signaling glycoproteins to a boronate-modified surface. Biosens. Bioelectron. 2012, 35, 355-362. [CrossRef] [PubMed]

39. Song, S.Y.; Yoon, H.C. Boronic acid-modified thin film interface for specific binding of glycated hemoglobin (HbA1c) and electrochemical biosensing. Sens. Actuators B Chem. 2009, 140, 233-239. [CrossRef]

40. Halámek, J.; Wollenberger, U.; Stöcklein, W.F.M.; Warsinke, A.; Scheller, F.W. Signal amplification in immunoassays using labeling via boronic acid binding to the sugar moiety of immunoglobulin g: Proof of concept for glycated hemoglobin. Anal. Lett. 2007, 40, 1434-1444. [CrossRef]

41. Stöllner, D.; Stöcklein, W.; Scheller, F.; Warsinke, A. Membrane-immobilized haptoglobin as affinity matrix for a hemoglobin-a1c immunosensor. Anal. Chim. Acta 2002, 470, 111-119. [CrossRef] 
42. Stöllner, D.; Warsinke, A.; Stöcklrin, W.; Dölling, R.; Scheller, F. Immunochemical determination of hemoglobin-A1c utilizing a glycated peptide as hemoglobin-A1c analogon. Biosens. Symosium Tubingen. 2001. Available online: http:/ / barolo.ipc.uni-tuebingen.de/biosensor2001/ (accessed on 4 August 2017).

43. Liu, G.; Khor, S.M.; Iyengar, S.G.; Gooding, J.J. Development of an electrochemical immunosensor for the detection of HbA1c in serum. Analyst 2012, 137, 829-832. [CrossRef] [PubMed]

44. Liu, G.; Iyengar, S.G.; Gooding, J.J. An amperometric immunosensor based on a gold nanoparticle-diazonium salt modified sensing interface for the detection of HbA1c in human blood. Electroanalysis 2013, 25, 881-887. [CrossRef]

45. Liu, G.; Iyengar, S.G.; Gooding, J.J. An electrochemical impedance immunosensor based on gold nanoparticle-modified electrodes for the detection of HbA1c in human blood. Electroanalysis 2012, 24, 1509-1516. [CrossRef]

46. Molazemhosseini, A.; Magagnin, L.; Vena, P.; Liu, C.C. Single-use disposable electrochemical label-free immunosensor for detection of glycated hemoglobin (HbA1c) using differential pulse voltammetry (DPV). Sensors 2016, 16, 1024. [CrossRef] [PubMed]

47. Qu, L.; Xia, S.; Bian, C.; Sun, J.; Han, J. A micro-potentiometric hemoglobin immunosensor based on electropolymerized polypyrrole-gold nanoparticles composite. Biosens. Bioelectron. 2009, 24, 3419-3424. [CrossRef] [PubMed]

48. Bian, C.; Tong, J.; Sun, J.; Zhang, H.; Xue, Q.; Xia, S. A field effect transistor (FET)-based immunosensor for detection of HbA1c and $\mathrm{Hb}$. Biomed. Microdevices 2011, 13, 345-352. [CrossRef] [PubMed]

49. Xue, Q.N.; Bian, C.; Tong, J.H.; Sun, J.Z.; Zhang, H.; Xia, S.H. CMOS and MEMS based micro hemoglobin-A1c biosensors fabricated by various antibody immobilization methods. Sens. Actuators A Phys. 2011, 169, 282-287. [CrossRef]

50. Xue, Q.N.; Bian, C.; Tong, J.H.; Sun, J.Z.; Zhang, H.; Xia, S.H. Antibody immobilization based on nano spheres modified by mixed SAMs and SPA for immuno-FET sensor fabrication. Nanotech. Precis. Eng. 2011, 9, 477-482.

51. Xue, Q.; Bian, C.; Tong, J.; Sun, J.; Zhang, H.; Xia, S. A micro potentiometric immunosensor for hemoglobin-A1c level detection based on mixed SAMs wrapped nano-spheres array. Biosens. Bioelectron. 2011, 26, 2689-2693. [CrossRef] [PubMed]

52. Xue, Q.; Bian, C.; Tong, J.; Sun, J.; Zhang, H.; Xia, S. FETimmunosensor for hemoglobin A1c using a gold nanofilm grown by a seed-mediated technique and covered with mixed self-assembled monolayers. Microchim. Acta 2012, 176, 65-72. [CrossRef]

53. Chopra, A.; Tuteja, S.; Sachdeva, N.; Bhasin, K.K.; Bhalla, V.; Suri, C.R. CdTe nanobioprobe based optoelectrochemical immunodetection of diabetic marker HbA1c. Biosens. Bioelectron. 2013, 44, 132-135. [CrossRef] [PubMed]

54. Ogawa, K.; Stollner, D.; Scheller, F.; Warsinke, A.; Ishimura, F.; Tsugawa, W.; Ferri, S.; Sode, K. Development of a flow-injection analysis (FIA) enzyme sensor for fructosyl amine monitoring. Anal. Bioanal. Chem. 2002, 373, 211-214. [CrossRef] [PubMed]

55. Fang, L.; Li, W.; Zhou, Y.; Liu, C.C. A single-use, disposable iridium-modified electrochemical biosensor for fructosyl valine for the glycoslated hemoglobin detection. Sens. Actuators B Chem. 2009, 137, 235-238. [CrossRef]

56. Chawla, S.; Pundir, C.S. An electrochemical biosensor for fructosyl valine for glycosylated hemoglobin detection based on core-shell magnetic bionanoparticles modified gold electrode. Biosens. Bioelectron. 2011, 26, 3438-3443. [CrossRef] [PubMed]

57. Chawla, S.; Pundir, C.S. An amperometric hemoglobin A1c biosensor based on immobilization of fructosyl amino acid oxidase onto zinc oxide nanoparticles-polypyrrole film. Anal. Biochem. 2012, 430, 156-162. [CrossRef] [PubMed]

58. Jain, U.; Chauhan, N. Glycated hemoglobin detection with electrochemical sensing amplified by gold nanoparticles embedded N-doped graphene nanosheet. Biosens. Bioelectron. 2017, 89, 578-584. [CrossRef] [PubMed]

59. Tsugawa, W.; Ishimura, F.; Ogawa, K.; Sode, K. Development of an enzyme sensor utilizing a novel fructosyl amine oxidase from a marine yeast. Electrochemistry 2000, 68, 869-871. 
60. Sode, K.; Takahashi, Y.; Ohta, S.; Tsugawa, W.; Yamazaki, T. A new concept for the construction of an artifical dehydrogenase for fructosylamine compounds and its application for an amperometric fructosylamine sensor. Anyl. Chim. Acta 2001, 435, 151-156. [CrossRef]

61. Sode, K.; Ohta, S.; Yanai, Y.; Yamazaki, T. Construction of a molecular imprinting catalyst using target analogue template and its application for an amperometric fructosylamine sensor. Biosens. Bioelectron. 2003, 18, 1485-1490. [CrossRef]

62. Yamazaki, T. An amperometric sensor based on gold electrode modified by soluble molecularly imprinted catalyst for fructosyl valine. Electrochemistry 2012, 80, 353-357. [CrossRef]

63. Rajkumar, R.; Katterle, M.; Warsinke, A.; Mohwald, H.; Scheller, F.W. Thermometric MIP sensor for fructosyl valine. Biosens. Bioelectron. 2008, 23, 1195-1199. [CrossRef] [PubMed]

64. Chien, H.-C.; Chou, T.-C. Glassy carbon paste electrodes for the determination of fructosyl valine. Electroanalysis 2010, 22, 688-693. [CrossRef]

65. Chien, H.-C.; Chou, T.-C. A nonenzymatic amperometric method for fructosyl-valine sensing using ferroceneboronic acid. Electroanalysis 2011, 23, 402-408. [CrossRef]

66. Sakaguchi, A.; Ferri, S.; Tsugawa, W.; Sode, K. Novel fluorescent sensing system for alpha-fructosyl amino acids based on engineered fructosyl amino acid binding protein. Biosens. Bioelectron. 2007, 22, 1933-1938. [CrossRef] [PubMed]

67. Kim, S.; Nibe, E.; Tsugawa, W.; Kojima, K.; Ferri, S.; Sode, K. Construction of engineered fructosyl peptidyl oxidase for enzyme sensor applications under normal atmospheric conditions. Biotechnol. Lett. 2012, 34, 491-497. [CrossRef] [PubMed]

68. Rajkumar, R.; Warsinke, A.; Mohwald, H.; Scheller, F.W.; Katterle, M. Development of fructosyl valine binding polymers by covalent imprinting. Biosens. Bioelectron. 2007, 22, 3318-3325. [CrossRef] [PubMed]

69. Pribyl, J.; Skladal, P. Development of a combined setup for simultaneous detection of total and glycated haemoglobin content in blood samples. Biosens. Bioelectron. 2006, 21, 1952-1959. [CrossRef] [PubMed]

70. Son, S.U.; Seo, J.-H.; Choi, Y.H.; Lee, S.S. Fabrication of a disposable biochip for measuring percent hemoglobin A1c (\%HbA1c). Sens. Actuators A Phys. 2006, 130-131, 267-272. [CrossRef]

71. Tanaka, T.; Tsukube, S.; Izawa, K.; Okochi, M.; Lim, T.K.; Watanabe, S.; Harada, M.; Matsunaga, T. Electrochemical detection of $\mathrm{HbA} 1 \mathrm{c}$, a marker [correction of maker] for diabetes, using a flow immunoassay system. Biosens. Bioelectron. 2007, 22, 2051-2056. [CrossRef] [PubMed]

72. Liu, A.; Xu, S.R.; Deng, H.Y.; Wang, X.C. A new electrochemical hba1c biosensor based on flow injection and screen-printed electrode. Int. J. Electrochem. Sci. 2016, 11, 3086-3094. [CrossRef]

73. Ahn, K.S.; Lee, J.; Park, J.M.; Choi, H.N.; Lee, W.Y. Luminol chemiluminescence biosensor for glycated hemoglobin (HbA1c) in human blood samples. Biosens. Bioelectron. 2016, 75, 82-87. [CrossRef] [PubMed]

74. Moon, J.M.; Kim, D.M.; Kim, M.H.; Han, J.Y.; Jung, D.K.; Shim, Y.B. A disposable amperometric dual-sensor for the detection of hemoglobin and glycated hemoglobin in a finger prick blood sample. Biosens. Bioelectron. 2017, 91, 128-135. [CrossRef] [PubMed]

75. Hirst, J.A.; McLellan, J.H.; Price, C.P.; English, E.; Feakins, B.G.; Stevens, R.J.; Farmer, A.J. Performance of point-of-care $\mathrm{HbA} 1 \mathrm{c}$ test devices: Implications for use in clinical practice-A systematic review and meta-analysis. Clin. Chem. Lab. Med. 2017, 55, 167-180. [CrossRef] [PubMed]

76. Saraoglu, H.M.; Selvi, A.O.; Ebeoglu, M.A.; Tasaltin, C. Electronic nose system based on quartz crystal microbalance sensor for blood glucose and HbA1c levels from exhaled breath odor. IEEE Sens. J. 2013, 13, 4229-4235. [CrossRef]

77. Vashist, S.K.; Luppa, P.B.; Yeo, L.Y.; Ozcan, A.; Luong, J.H. Emerging technologies for next-generation point-of-care testing. Trends Biotechnol. 2015, 33, 692-705. [CrossRef] [PubMed] 
78. Pandey, R.; Paidi, S.K.; Valdez, T.A.; Zhang, C.; Spegazzini, N.; Dasari, R.R.; Barman, I. Noninvasive monitoring of blood glucose with raman spectroscopy. Acc. Chem. Res. 2017, 50, 264-272. [CrossRef] [PubMed]

79. Spegazzini, N.; Barman, I.; Dingari, N.C.; Pandey, R.; Soares, J.S.; Ozaki, Y.; Dasari, R.R. Spectroscopic approach for dynamic bioanalyte tracking with minimal concentration information. Sci. Rep. 2014, 4, 7013. [CrossRef] [PubMed]

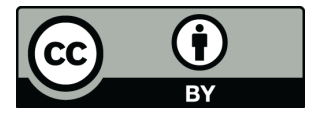

(C) 2017 by the authors. Licensee MDPI, Basel, Switzerland. This article is an open access article distributed under the terms and conditions of the Creative Commons Attribution (CC BY) license (http://creativecommons.org/licenses/by/4.0/). 